\title{
The Impact Of Group Counseling Intergrated With Creative Drama On The Level Of Shyness
}

\author{
Emine DURMUŞ***
}

\begin{abstract}
In this research, the impact of group counseling integreated with creative drama on the level of shyness is analaysed. In this research, split-plot design including pre-test and post-test of the control group is employed. Upon completion of the group program applied with experimental group and conrol group is applied as post-test, the shyness scale adapted by Güngör (2001). The group program designed to solve the shyness problem is developed by researcher. The program is integrated with creative drama techniques and based on cognitive-behavioral approach, wich include role-playing, dramatizing and improvisation. In this research, split-plot design including pre-test and post-test of the conrol group is employed. The result showed that the program's effect of shyness levels reducing has increasingly continued. As the results are taken, considered and discussed as sufficient proofs for the effectivenes of the group program coping with shyness.
\end{abstract}

Key Words: Shyness, creative drama, group counseling.

\footnotetext{
This study is a summary of the thesis submitted to tha Ankara University for the degree of Doctor of Education.

Dr., Inonu University, Faculty of Education, edurmus@inonu.edu.
} 


\section{SUMMARY}

Purpose And Significance:In this research, the impact of group counseling integreated with creative drama on the level of shyness is analaysed. Research suggests that, courtesy of changing cultural conditions, the incidence of shyness in the society, may now be as high as 48 per-cent--and rising. Most shyness is acquired through life experiences. At the core of our existence as human beings lies a powerful drive to be with other people. Research demonstrates that these temperaments are stable over extended periods of time. Social ties seem to impact stress hormones directly, which in turn affect almost every part of our body, including the immune system. They also improve mental health. Having large social networks can help lower stress in times of crisis, alleviate depression and provide emotional support.

In this research, the impact of group counseling integreated with creative drama on the level of shyness is analaysed. The research is conducted with 34 students randomly selected among freshmen students whose shyness level is high. The study carried out during the 20032004 academic year. In this research, split-plot design including pre-test and post-test of the conrol group is employed. Besides the treatment group of 17 subjects, a placebo control group of 17 subjects is also designated in order to conrol Hawthorne effect. The group program designed to solve the shyness problem is developed by researcher. The program is integrated with creative drama techniques and based on cognitive-behavioral approach, wich include role-playing, dramatizing and improvisation. The group program is performed once a week for 10 weeks. Each session lasts 2.5 hours on average. Upon completion of the group program applied with experimental group and conrol group is applied as post-test, the shyness scale adapted by Güngör (2001).

Methods: The aim of this research the impact of group counseling integreated with creative drama on the level of shyness is analaysed. In order to test whether the program's reduction effect on shyness level is long lasting the experimental group's post-test scores and follow-up test (at 4 months) scores, were conpared. The research is conducted with 34 students randomly selected among freshmen students whose shyness level is high. The study carried out during the 2003-2004 academic year in the Ankara University. In this research, split-plot design including pre-test and post-test of the control group is employed. Upon completion of the group program applied with experimental group and conrol group is applied as post-test, the shyness scale adapted by Güngör (2001). As a result it was found that shyness level of the subject in the treatment group, as compared to the subjects in the control group dramatically decreased. The group program designed to solve the shyness problem is developed by researcher. The program is integrated with creative drama techniques and based on cognitive-behavioral approach, wich include role-playing, dramatizing and improvisation.

Results: In this research, split-plot $(2 \times 3)$ design including pre-test and post-test of the conrol group is employed. The result showed that the program's effect of shyness levels reducing has increasingly continued. As the results are taken, considered and discussed as sufficient proofs for the effectivenes of the group program coping with shyness.

Discussion and Conclusions: Creative drama and group program for shyness level increasingly can be used. As the results are taken considered and discussed as sufficient proofs for the effectivenes. 


\title{
Yaratıcı Drama İle Bütünleştirilmiş Grupla Psikolojik Danışmanın Üniversite Öğrencilerinin Utangaçlık Düzeylerine Etkisi
}

\author{
Emine DURMUŞ***
}

\begin{abstract}
ÖZ. Bu araştırmada, yaratıcı drama ile bütünleştirilmiş grupla psikolojik danışmanın üniversite öğrencilerinin utangaçlık düzeylerine etkisi incelenmiştir. Araştırmada öntest-sontest kontrol gruplu (split-plot) desen kullanılmıştır. Araştırmanın bağımsız değişkeni deney grubunda uygulanan programdır. Bağımlı değişkeni ise öğrencilerin utangaçlık düzeyidir. Araştırmada Göngör (2001) tarafından Türkçe'ye uyarlanan utangaçlık ölçeği kullanılmıştır. Araştırmacı tarafindan geliştirilen yaratıcı drama ile bütünleştirilmiş utangaçlık programı, ağırlıklı olarak bilişsel-davranışcı yaklașımı temel alarak, yaratıcı dramanın rol oynama, dramatizasyon, doğaçlama vb. tekniklerine dayalı olarak hazırlanmıştır. Grupların utangaçlık düzeyleri arasında anlamlı fark olup olmadığını ve bu farkın uzun süreli olup olmadığını, belirlemek amacıyla split-plot analiz tekniği kullanılmıştır. Bulgular deney grubunda yer alan öğrencilerin kontrol grubundaki öğrencilere kıyasla utangaçlık düzeylerinin anlamlı düzeyde azaldığı ve bu azalmanın olumlu etkisinin uzun süreli olduğunu ortaya koymuştur. Sonuçlar literatür 1şığında tartışılarak, öneriler sunulmuştur.
\end{abstract}

Anahtar Kelimeler: Utangaçlık, yaratıcı drama ve grupla psikolojik danışma

\footnotetext{
Bu çalışma Ankara Üniversitesi Eğitim Bilimleri Enstitüsü'nde Prof.Dr.Üstün DÖKMEN Danışmanlığında yapılmış "Yaratıcı Drama İle Bütünleştirilmiş Grupla Psikolojik Danışmanın Üniversite Öğrencilerinin Utangaçlık Düzeylerine Etkisi” adlı doktora tezinden özetlenerek hazırlanmıştır.

** Yard.Doç.Dr. İnönü Üniversitesi Eğitim Fakültesi, edurmus@inonu.edu.tr
} 


\section{GÍRIŞ}

İlk kez Zimbardo'nun 1975 yılında "Utangaçlık Denilen Toplumsal Hastalık" başlıklı makalesi ile gündeme gelen utangaçlık, o tarihten bu yana pek çok araştırmaya konu olmuştur. Araştırmalara göre günümüzde her iki kişiden biri kendisini utangaç olarak görmektedir. Toplumda utangaç insanların oranı gittikçe artıyor. Üniversite öğrencilerinin bile önemli bir bölümü (\%40) kendilerini utangaç olarak algılamaktadır. Teknolojik gelişmeler, toplumda artan utangaçlığı gün geçtikçe bir "utangaçlık kültürü"ne dönüştürmektedir (Cardduci ve Zimbardo, 1995). İnsanların büyük bir bölümü yaşamının tüm evrelerinde, ama her insan yaşamının belirli evrelerinde utangaçlık yaşamaktadır (Crozier,2001). Utangaçlık; başkaları tarafından olumsuz değerlendirilme korkusu (Buss,1986), sosyal ortamlarda yaşanan huzursuzluk, sıkılganlık, ürkeklik ve çekingenlik duygusu ve (Henderson ve Zimbardo,1998) otorite tarafindan değerlendirilme (Crozier,2001) korkusunu da içeren, sosyal ortamlarda yaşanan huzursuzluk ve endişe olarak tanımlanmaktadır (Cardduci ve Zimbardo, 1995).

Başkalarının bulunduğu yerde yaşanan 'tedirginlik ve kısıtlanma duygusu' olarak da tanımlanan utangaçlık; kişilerarası ilişkileri etkileyen önemli etmenlerden biridir (Jones, Briggs ve Smith, 1986). Utangaçlığı toplumsal bir rahatsızlık olarak niteleyen Zimbardo'ya (1977) göre utangaçlık; bireyin toplumsal olaylar karşısında yaşadığ 1 beceri eksikliğinin sonucu olmaktan çok, bireyin toplumla bütünleşme çabasının doğurduğu davranışlardır. Temel bir yaradılış olarak da ifade edilen utangaçlığın (Buss ve Plomin,1984), tanımlanmasında farklı kavramlar kullanılmaktadır. Cheess ve Thomas (1986), utangaç çocukları 'yavaş ısınan' çocuk; Caspi (1998), 'çekingen' çocuk gibi tanım ve kavramlarla kategorize etmektedir. Utangaçlıkla ilgili yapılan tanımlar incelendiğinde neredeyse her araştırmacının kendi tanımını yaptığı görülmektedir. Bazı tanımlarda utangaçlık içedönük dışa dönük ayrımından hareket edilerek açıklanırken, bazı tanımlarda çekingen davranışlar ile bağ kurularak açıklanmaktadır. Tanımların birleştiği ortak genel noktalar da vardır, buna göre; utangaçlık sosyal durumlarda rahat olmayı, başkaları ile sağlıklı ilişkiler kurmayı, yeni insanlarla tanışmayı zorlaştıran bir özelliktir. Sonuç olarak, utangaçlıkla ilgili denilebilir ki, başkalarının bulunduğu ortamlarda yaşanan tedirginlik ve kısıtlanma duygusu ile ortaya çıkan ve kişilerarası ilişkilerde güçlük yaşanmasına neden olan, temelinde eleştirilme korkusu olan bir duygudur.

Araştırma bulguları (Carducci, 2000), utangaçların \%75'nin yabancıların bulunduğu ortamlarda, \%71'i karşı cinsten bireylerin bulunduğu gruplarda, \%65'i karşı cinsten bireylerle bire bir kalındığ 1 durumlarda, \%56'sı aynı cinsten kişilerin olduğu gruplarda, \%45'i aile bireylerinin dışındaki akrabaların olduğu gruplarda, \%38'i aynı cinsten bireylerle bire bir kalındığı durumlarda, \%22'si ailelerinin olduğu ortamlarda ve \%20'si kardeşlerinin bulunduğu gruplarda utangaç olduklarını ifade etmektedirler. Ayrıca, utangaçların \%46'sı utangaçlığın üstesinden gelinebilecek bir sorun olduğunu düşünürken, \%7.2'si üstesinden gelinebileceğine inanmadıklarını ifade etmişlerdir, Yine utangaç bireylerin \%85'i utangaçlıklarıyla başetmede gönüllü olduklarını ifade etmektedirler. 


\section{Utangaçlığın Kaynağı ve Nedenleri}

Utangaçlı̆̆ın nedenine ilişkin farklı görüşler öne süren bir çok araştırma vardır (Zimbardo, 1977; Pilkonis, 1977; Barrow ve Hayashi, 1980; Cheek ve Buss, 1981; Clements ve Avey, 1984; Henderson ve Zimbardo, 1998; Carducci, 2000; Kagan, 2002; Yüksel, 2002; Erdal, 2003). Araştırma sonuçları bu olağanüstü zor olayın bir çok belirleyicisi olduğuna işaret etmektedirler. Bazı bireylerde utangaçlık iletişim kurmaya dair endişelerden kaynaklanırken; bazılarında iletişim becerisi eksikliğinden, ya da söylenecek bir şeyin olmadığı, söylense de anlaşılması zor şeyler söyleyeceği korkusundan kaynaklanmaktadır. Sonuçta, nedenler farklı olsa da sonuç aynıdır, birey iletişime girmez, girmek istemez (Duck,1986), başkalarının bulunduğu ortamlarda rahat davranamaz, insanlarla iletişim kurmakta güçlük yaşar.

Utangaçlığı genetik, aile ilişkileri, kişilik özelliği ile açılayan görüşler vardır. Utangaçlı̆̆ın temel bir yaradılış olduğunu öne süren ve çalışmalarını çoğunlukla çocuklar üzerinde gerçekleştiren Kagan (1992)'a göre, utangaçlık doğuştan gelen bir özelliktir ve doğan bütün bebeklerin \%20'si “çekingen karakterli" olarak doğmaktadırlar. Utangaçlığın genetik geçişini incelemek için ikizler üzerinde çalışma yapan Fyer ve diğerleri (1993) tek yumurta ikizlerinde utangaç davranışı, çift yumurta ikizlerine göre daha çok birbirine benzer bulmuş olsalar da, utangaçlığın nedenlerine ilişkin, genetik etkinin yanında, çevresel etkinin olduğu da gözardı edilemez.

Kagan (1992) doğuştan utangaç olduğumuzu savunsada, Crozier (2001)'e göre, yaşamın ilk yıllarından beri varolan utangaçlık, çocukluk dönemindeki engellenmenin sonucudur. "Utangaçlığa Yeni Bir Bakış" adlı makalesinde Carducci (2000), kesinlikle utangaç olarak doğmadığımızı savunur. Ona göre utangaç birey bu özelliği doğuştan getirmez, sonradan kazanır ve birey bu özelliğinin farkındadır. Utangaç bireylere "neden çekingen davrandıkları" sorulduğunda, kaygılarının nedenini belirlemek amacıyla verilen cevaplar değerlendirildiğinde; utangaç bireylerin \%40'ı bu kaygılarının ailelerinden kaynaklandığını ifade etmiş̧lerdir. Yine utangaç olan bireylerin \%20'si utangaçlıklarının nedenini düşük özsaygı düzeyine sahip olmalarına ve reddedilme korkusuna dayandırmışlardır.

Utangaçlık, son yıllardaki araştırmalarda (Cheek ve Buss,1981; Loran, Henderson ve Zimbardo, 2000; Hendersen ve Zimbardo, 2001) bir kişilik özelliği ve bu özelliğe dayalı olan bir davranış olarak tanımlanmaktadır. Utangaçlık herkeste az ya da çok, belirli bir derecede bulunan bir özelliktir. Bu dağılım insanların boy uzunluğu arasındaki dağılıma benzer, bazı insanlar kısa, bazıları uzun boylu olarak tanımlanırken, büyük oranda insan normal boy aralığında olarak kabul edilmektedirler. Çok utangaç olan bireylerin utangaç olmaları nedeni ile dışarı çıkmak, yeni arkadaşlar edinmek, yüzyüze ilişkiler gerektiren ve işinde yüksek sorumluluk alabilecek pozisyonlara ulaşma gibi konularda yoğun sorunlar yaşadıkları bilinmektedir (Stein ve Walker, 2001). Utangaçlığın genel olarak, bireylerin kişisel özelliklerinde saklı olduğu savunulsa da, Eysencek (1983)'in kişilik kuramında utangaçlığın yeri açık değildir. Bazen içedönüklük, bazen de psikolojik rahatsızlıkların içinde ele alınmıştır. Utangaçlığı, "yabancılarla ilişsi 
kurma güçlüğü, sosyal ilişkilerde yetiştiği ortamı saklama eğilimi” olarak ele alan Eysencek, utangaçlığın iki türü olduğunu öne sürmektedir. Birincisi; bireyin insanları dikkate almadığı, yalnız olmayı tercih ettiği, fakat gereksinim duyarsa da etkin bir biçimde sosyal olaylarda yer alabildiği, içedönük utangaçlıktır. İkincisi ise; bireyin rahatsız olmasıyla ilgili sıkıntılarının olduğu, yalnızlık duygusu yaşadığı, aşağılık duygusuna sahip olduğu, nörotik utangaçlıktır.

Amico ve diğerleri (2003) çalışmalarında utangaçlığın temelinde olumsuz değerlendirilme korkusu olduğunu savunmaktadırlar. Utangaçlığı, başka insanların olumsuz geri bildirimleri ya da onlar tarafindan onaylanmama ihtimalinin yarattı̆̆ 1 endişe olarak tanımlamaktadırlar. Utangaç bireyler olumsuz değerlendirilme korkuları nedeniyle kendilerini yetersiz, sosyal ilişkilerde başarısız ve normal yaşam standardının altında performans sergileyen insanlar olarak tanımlamaktadırlar.

Utangaçlığın aile ilişkileri ve çocukluk yaşantılarına ait ilişkileri ele almak amacıyla, aileye ait faktörleri araştıran bir çok çalışma da (Thomas ve Chess, 1977; McDevitt ve Carey, 1981; Peters-Martin ve Wachs,1984;) aileye ait faktörlerin ne kadar önemli olduğunun altını çizmektedir. Bu sonuçlara göre; ilk iki yaşa kadar yeni durum, insan ve objelerle karşılaşıldığında yaşanılan korku ve geri çekilmede, yasaklama ve çekinme duygusunun önemi büyüktür. Özellikle çocukluk yıllarında yoğun olarak, engellenme ve yasaklanma davranışlarıyla karşılaşan bu çocukların gelişme çağında ya da sonraki yıllarda depresyon, içe kapanma gibi sosyal endişe problemleri gibi tehlikelerle karşı karşıya olabilecekleri görüşü de bu araştırmalar sonunda öne sürülen bulgular arasındadır (akt.Crozier, 2001).

Utangaçlı̆̆ın nedenleri arasında sayılan faktörlerden birinin aile yapısının olduğu yönündeki görüşlerden biri de Crawfor ve Taylor'a (2001) aittir. Buna göre, insanlar genellikle aile davranış kalıpları tarafindan yoğrulup biçimlendirilir. AnneBaba kendini kararlılıkla ifade edemeyen kimselerse, çocuğun büyüyünce silik bir insan olma olasılığı yüksektir. Aynı biçimde anne baba aşırı eleştirici bir tavır sergileyerek çocuğu sürekli eleştiriyorsa, çocuk da kendini mükemmel görememe ve iyi şeylere layık olmadığı düşüncesini yerleştirecektir. Utangaç davranmayı utangaç ana-babalardan kolayca öğrenebiliriz. Çok utangaç, çok gergin ve çok sinirli insanlar genelde bu davranış kalıbını ailenin diğer üyelerine de aşılarlar. Dünyaya özgüveni olan bireyler olarak gelsek bile, özgüveni olmayan, kendini değerli ve sevilmeye layık bulmayan anne-babaların yetiştirme yöntemi ile bu güven yok edilebilir (Crawford ve Taylor, 2001).

Utangaçlık duygusunda büyük oranda öğrenmenin çağrışımı olsa da, yasaklanma düşüncesi bireyin ilk yıllarında kişilik gelişimi bakımından önemlidir. Özellikle yaşamın ilk yıllarında gösterilen engelleyici tepkiler ve yeniliklere karşı korku gibi karakteristik özellikler, bireyin yaşamının ilk yıllarında karşı karşıya kaldığı engelleyici tepkilere bağlanabilir. Bu sonuçlar yaşamın ilk yıllarında özellikle anneye özgü nedenlerin ne kadar önemli olduğunu göstermektedir (Asendorpf ve Wilpers,1998). 
Psikososyal gelişim kuramına göre 1-3 yaş arası özerklik (bağımsızlık) isteğinin belirgin olduğu dönemdir. Bu dönemde çocuk birbirine karşı duygu ve eğilimler arasında bir denge kurmaya çalışır. Özellikle bu dönemde anne baba ve çevrenin yoğun baskısı ve anlamsız engellemeleri, çocuğun sürekli suçlu hissetmesine neden olmakta ve çocukta utanç duygusunun yerleşmesine yol açmaktadır. Sonuçta aşırı bağımlı, aşırı boyun eğen ve aşırı utangaç, kuşkulu ya da isyancı, kararsız kişilikler gelişmektedirler (Ekşi, 1990). Özerk insanlar, engeller ve zorluklarla dolu bir dünya da kendi yolunu bulabileceklerine emin bireylerdir. Bu dönemde Erikson aşırı korumacı anne-babalığa yönelik önemli uyarılarda bulunmaktadır. Erikson'a göre eğer anne babalar çocuklarını aşırı bir şekilde korursa, gelişimlerini engelleyebilirler. Çevrelerindeki nesneleri ve olayları keşfetme ve etkileme izni verilmeyen çocuklar, utanç ve șüphe duyguları geliștirirler ve kendilerinden emin olmayan ve başka insanlara bağımlı yaşayan insanlar olurlar (Burger,2006). Özerkliğe karşı utanma ve şüphecilik dönemini, girişkenliğe karşı suçluluk duygusunun yaşandığı erken çocukluk dönemi takip eder. Üç yaşını tamamlayan çocuğun altıncı yaşın sonuna kadar başarması gereken temel görev, girişimciliğe karşı suçluluk karmaşasını çözümlemektir. Bu dönemde çocuk sorunları ile başa çıkabilmek için daha bağımsız davranmaya başlar. $\mathrm{Bu}$ dönemelerdeki aşırı engeller, sonraki yıllarda utangaçlığın habercisi olabilmektedir.

Son zamanlarda utangaçlığın nedeni ile ilgili bilinen modellerin en etkili olanlarından biri Clark ve Wells(1995) tarafindan öne sürülmüştür. Bu modele göre kişi, kendisinin algıladığı, anlattığı ve gerçekleşeceğine inandığı bazı korkulara sahiptir. Bu korkuları onun davranışlarını etkiler. Bu düşünce ile sonunda korkulanın olması, bu konudaki güvensizliğini pekiştiren sonuçlar olarak bireye tekrar döner. Birey ne zaman böyle bir korkuyu tehdit olarak algılarsa, aynı başarısızlık kendini tekrar eder. Örneğin, birey utandığında yüzünün kızaracağı korkusunu yoğun olarak yaşıyorsa, yüzünün kızarmasından korkan birey davranışları dikkat çektiği zaman korkulan sonuca daha kolay ulaşmakta, yani yüzünün kızarması daha fazla olmaktadır. Bu sonuç birey için daha büyük problemlerin oluşmasına da neden olmaktadır. Sonraki dönemlerde ise çözüm olarak, alkol ya da diğer ilaçların kullanılması, sosyal durumlarda yaşanan sıkıntılarla başetmek için seçilen yollardan biri olmaktadır. Tüm bu ipuçları göstermektedir ki utangaçlık kavramı görünüşte yalın, günlük yaşamda yaygın olmasına rağmen bilimsel olarak araştırılması zor ve karmaşık konulardan biridir (Carducci, 2000).

Sonuç olarak, utangaçlığı belirgin bir kategoride ele alıp değerlendirmek bu günkü bilgilerimizle güçtür. Utangaçlık davranış boyutunda ele alındığında bireyde gözlenen davranışların gizli ya da açık olmasıyla farklı bir boyut kazanmaktadır. Kaynağı ve oluşma nedenleri açısından ele alındığında genetik geçişli olduğu ya da sosyal deneyimlerle sonradan kazanıldığı yönündeki ayrım utangaçlığı açıklamak açısından iki farklı bakış açısı getirmektedir. 


\section{Utangaçlığın Bireyin Yaşamına Etkileri}

Utangaçlık, bireylerin genelde yaşamlarını, özelde ise eğitim yaşamı, meslek yaşamı, arkadaş ve aile yaşamını etkileyen bir etkendir. Bir çok insan için utangaçlık, temel gereksinimlerin önündeki bir engeldir. Utangaçlık kişiyi kontrol eder ve onları sınıf ortamında, sosyal ortamlarda ve iş ortamında daha az etkin yapar (Carducci, 2000).

Utangaçlıkla ilgili yapılan araştırma sonuçları (Simith ve Betz, 2002; Jackson ve diğerleri, 2002; Walsh, 2002; Heiser ve diğerleri 2003; Yüksel, 2003; Netro ve Mullet, 2004) utangaç bireylerin, diğer bireylerden daha fazla yalnızlık ve depresyon yaşamakta olduğunu göstermektedir. Yalnızlık ve depresyon yaşayan utangaç kişilerin yeni arkadaşlık ilişkileri kurmaları güçleşmekte ve bu sonuç utangaçların toplumsal sorunları daha yoğun yaşamalarına neden olmaktadır. Utangaçlık yaşayan bireyler, bir yandan başkaları yanında fark edilen ve önemsenen insanlar olmayı arzu ederken, öte yandan da toplumda fark edilmemenin getirdiği sıkıntılar ile baş etmek zorunda kalmaya bağlı olan çift yönlü korkularla başetmeye çalışırlar (Cardduci ve Zimbardo,1995).

Utangaçlığın bireylerin yaşamındaki en önemli etkilerinden biri de utangaçlıkları nedeni ile yalnız kalmalarıdır. İletişim kurmada yetersiz olan utangaçlar diğer insanlarla içten iletişimler kuramazlar, bu durum utangaçların ilişskilerinde ilgisiz olarak algılanmalarına neden olmaktadır. $\mathrm{Bu}$ durumun doğuracağı en temel sonuç da yalnızlıktır (Cheek ve Busch,1981).

Utangaç kişiler kendileriyle ilgili endişe yaşarlar ve kendileri hakkında olumsuz düşüncelere sahiptirler. Sosyal ortamlardaki hoşnutsuzluğu abartma eğilimleri ve başkalarının göstermiş olduğu olumsuz tepkilerden kolaylıkla etkilenme olasılıkları yüksektir. Kendileriyle ilgili olumsuz yargılar, utangaç bireyin yüksek özsaygı geliştirmesine engel olmaktadır. Bu kişiler, sosyal ortamlarda kaygıdan ziyade bilişsel anlamda bir rahatsızlık yaşamaktadırlar. Utangaç bireyler, sosyal ortamlara katılamazlar, konuşmakta zorlanırlar ve diğer insanlara az ilgi gösterirler. $\mathrm{Bu}$ da onların yalnızlığa itilmelerine ve kendilerini yalnız hissetmelerine neden olur (Henderson ve Zimbardo,1988). Utangaç öğrencilerin büyük çoğunluğunun kronik yalnızlık çekmeleri yüksek bir olasılıktır (Asendorpf ve Meier 1993).

Kendine güvenme, kendini ifade edebilme, bireyin yaşamının bir çok bölümünde gereksinim duyacağı özelliklerdir. Buna karşın utangaç bireyin özellikleri düşünüldüğünde bu durumlarda başarılı olma olasıllğının oldukça az olduğu söylenebilir. (Arends, 2000). Asendorpf ve Meier'in (1993) utangaçlığın üniversite öğrencileri üzerindeki etkisini incelediği araştırmasının sonuçlarına göre, utangaçlık tartışma götürmez bir biçimde kişilerarası ilişkileri olumsuz etkilemektedir. Utangaç öğrencilerin romantik bağlılık içeren yeni ilişkilere başlamakta daha fazla problemlere sahip olduğu ortaya konmuştur. Utangaç olmayan öğrencilerin üç ay süresinde eriştikleri çevreye, utangaç öğrencilerin ulaşması bir yıl almaktadır. Leary ve Dobbins (1983) utangaçlı̆̆ın karşı cinsle ilişkileri üzerinde ciddi sonuçları olduğu görüşünü savunmaktadır. Utangaçlık düzeyi yüksek kişilerin, utangaç olmayanlara göre daha az cinsel deneyim yaşadıklarının altı çizilmiş̧tir. 
Utangaç bireylerin bu özelliklerine bakıldığında ana-baba ya da eğitimciler açısından görünürde istenilen özellikler oldukları söylenebilir. Bu özellikler bazı ana-babalar ve öğretmenler açısından tercih edilen "uslu çocuk" beklentisine uyan özellikler olmasına karșın; sağlıklı gelişim açısından tercih edilen özellikler değildir. Gelişim kuramcılarına göre bireyin her dönemde kazanması gereken gelişim görevleri vardır. Bu görevler genel anlamda gelişim dönemlerine uygun, ama bireye özgü olarak gerçekleşirler. Gelişim sürecinde geleneksel roller ve beklentilerin etkisinde kalan birey, kültürün pekiștirdiği özellikler geliștirebilir. Bireyin kazandığı pek çok özellik gibi utangaçlı̆̆ın oluşmasında da kültür, toplumsal roller ve ailenin yetiştirme tarzının önemli etkisi vardır.

Utangaç bireyin gelişim alanlarını sağlıklı tamamlaması biraz da utangaçlıkla başetmesine bağlıdır. Bu nedenle utangaçlık uzun yıllar dünya da ve özellikle 2000'li yıllarda Türkiye'de pek çok araştırmaya (Göngör,2001; Cabak,2002; Gökçe,2002; Erdal, 2003; Hasdemir,2005; Yüksel, 2003) konu olmuştur.

$\mathrm{Bu}$ araștırmanın amacı, yaratıcı drama ile bütünleştirilmiş grupla psikolojik danışmanın üniversite öğrencilerinin utangaçlık düzeyleri üzerindeki etkisini incelemektir.

\section{Grupla Psikolojik Danışma Sürecinde Yaratıcı Drama}

Utangaçlıkla başetmede sosyal beceri eğitimi, davranışçı yöntemler, bilişsel davranış̧̧ terapiler, gibi yöntem ve yaklaşımlar önerilmektedir (Duck, 1986). Bu araştırmada yaratıcı drama yöntem ve tekniklerinin kullanıldığ grupla psikolojik danışma uygulamalarının yapılması ve bir yöntem olarak utangaçlıkla başetmede yaratıcı dramanın grupla psikolojik danışma süreçlerinde kullanılması amaçlanmıştır.

Drama; bireyin kendisi ve çevresindekilerle ilgili, fiziksel ve ruhsal, bireysel ve toplumsal, insanın gerçek durumu ve içindeki potansiyeli gibi bireyin bütününü kapsayan etkinlikleri içine almaktadır. İçten gelen fikirlerin, duyguların estetik ve ahlak kuralları dahilinde dışa vurumu, bireyin sağlıklı gelişimini etkiler. Sosyal büyüme yaratıcı dramanın tanımında ortak bir amaçtır. Drama, öncelikle bireyin kendini kabul ederek, anlayarak ve sonra da başkalarını kabul ederek sosyal gelişimi kolaylaştırmaktadır. Yaratıcı drama özellikle dramaya katılanlara duygusal bir rahatlama ve tehditsiz bir çevrede sosyal becerileri geliştirme ve yapıcı davranışları deneme, işbirliği ve dayanışmayı öğrenme firsatı verir. Drama insanın bütünüyle ilgilidir. Bireyin kişisel, duygusal sosyal ve diğer problemlerini araştırması ve çözümler bulması için firsatlar verir. Bu etkinlikler bireyin duygusal gelişiminde ve duygularını kontrol etmede pekçok beceri geliştirmesine yardım etmektedir (Freeman, Sullivan ve Fullton, 2003).

Yaygın olarak sosyal yetenekleri geliştiren bir yöntem olarak önerilen yaratıcı drama (Freeman, Sullivan ve Fullton, 2003) her yaşta bireyin sosyal ve kişilerarası becerilerinin geliştirilmesinde de etkili bir yöntemdir. Özellikle topluluk içerisinde kendini ifade etmekte güçlük yaşayan bireyin küçük gruplar içerisinde küçük oyunlarla bu güçlüğünü yenmesi daha kolay olmaktadır. 
Piaget'ye göre, yaratıcı drama narsist ve utangaç duyguları tanımada yeni bir yön oluşturmaktadır. Drama bireylerin birbirleri ile aynı olmadığını görmelerini ve gelişimdeki farklılıkları anlamayı kolaylaştırmaktadır. $\mathrm{Bu}$ sonuç daha esnek ve toleranslı bir toplum yaratmada etkili bir yöntemdir (Freeman,Sullivan ve Fulton,2003). Dramanın doğasında insanın insanla karşılaşmasında ortaya çıkan bir olgu olan etkileşim vardır. Yaratıcı drama süreçlerinde bireyin sosyalleşmesi, güven ve saygi duygusunun gelişmesi, bir grubun üyesi olmakla beraber iletişim ve problem çözme becerileri de kazandırmaktadır (San,1989).

Bazı teknolojik avantajlar, internet, mail, cep telefonu içinde yaşadığımız kültürün koşullarını, hızlandırarak ve karmaşıklığını şiddetlendirerek, değiştirdiği artık sır değildir. Toplumumuz artık yalnızca daha hızlı olmuyor, daha gürültülü ve daha gösterişli oluyor. İnsanlar farkında olmadan daha uç noktalarda yer alıyorlar, ya yaklaşıyoruz, ya kaçıyoruz; yani ya saldırganlaşıyoruz, ya da geri çekilip utangaç oluyoruz. Yüksek kültür diye sunulan bu olgu, utangaçlar için günlük etkileşimin negatif sonuçlarını günden güne azar azar değiştirmektedir (Carducci, 2000). Bu kültürel iklimde, insanlar gittikçe herşeyin daha hızlı olmasına alışık olduklarından, tahammül çabucak kaybedilmektedir. Isınmak için ek zamana ihtiyaç duyan diğer insanlara karşı daha az hoşgörülü olmaktadırlar. Hızlı olmayan ve yoğun olmayanların gözardı olduğu bu iklim büyük oranda ilk etkilerini utangaçlar hissetmektedirler. Bu kültür utangaçlığın hem derecesi ve hem de varolmasını şaşırtıcı bir şekilde arttırmaktadır.

Bireyin gelişim alanlarını sağlıklı tamamlamaları için yaratıcı drama da psikolojik danışma ve rehberlik hizmetlerinde kullanılabilecek uygun bir yöntemdir. Milli Eğitim Bakanlığınca "yeni kuşakların toplum yaşamında yerlerini almak üzere hazırlanmaları ve bunun için gerekli bilgi, beceri ve davranışları geliştirmeleri ve kazandırılması süreci" olarak tanımlanan eğitim amacı, Rehberlik ve Yaratıcı Drama gibi her iki disiplinin de ortak amacı olarak karşımıza çıkmaktadır. Yaratıcı dramada da Psikolojik danışma ve rehberlik çalışmalarında gerçekleştirilen grup çalışmalarında olduğu gibi, grup etkinlikleri olarak yürütülür. Yaratıcı drama etkinliklerine katılmakta gönüllülü̈k esastır. Grup sürecini bir lider yönlendirir. Grupta yeralan birey grup etkileşimi yoluyla konu ya da temaları yaşar, dener ve öğrenir. Etkin bir katılım vardır. Bireyin kazandığı ya da kazanacağı tüm beceriler onun katılımı ile gerçekleşebilir (Adıgüzel, 1994).

Utangaçlıkla baş etmek için öncelikle bireyin sosyal ortamlarda aklına gelen düşüncelerin nasıl uyumsuz olabileceğinin, kendisine ve başkasına ilişkin temel inançlarının bazen nasıl gerçekçi olmadığını ve toplumsal kaynaklı tehlike beklentilerinde nasıl yanılmış olabileceğini görmesi gerekir. Bireyin toplumda davranışlarını zorlaştıran uyumsuz otomatik düşüncelerinin farkına varması, otomatik düşüncelerin oluşumuna kaynaklık eden gerçekçi olmayan inançlarını fark etmesi önemlidir (Markway ve diğerleri, 1998).

Çekingen bireylerin terapisinde bilişsel yapılandırma tekniklerine ek olarak özellikle çekingen davranışların ortadan kaldırılmasında, yeni becerilerin öğrenilmesinin kaçınılmaz olduğu durumlarda sosyal beceri eğitimleri de zorunlu 
görünmektedir (Yolaç,1998). Sosyal beceri eğitimi programları, iletişimle ilgili yetersizlikleri hafifletmede etkilidir. Utangaç bireylerin konuşmaya dayalı becerileri eksik olduğundan, hareket noktası çoğunlukla utangaç insanları konuşmaya dayalı yeteneklerini geliştirmektir. Konuşmaya dayalı bu yetersizlik bireylerin doğru sorular sormalarını, etkili bir biçimde davetlerde bulunmalarını, kendileriyle ilgili açıkça ve kolayca konuşmalarını engeller. Model alarak, örneklerle ya da geri bildirimlerle onların konuşmaya bağlı yetersizliklerinin giderilmesi, utangaçların beceri eksikliğinden gelen suskunluklarının üstesinden gelmelerine yardımcı olacaktır (Kelly, 1982).

Sosyal beceri eğitimi içerisinde yeralan modelden öğrenme, rol oynama, geribildirim verme, ev ödevi, pekiştirme gibi yöntem ve teknikler bireyin utangaçlığını azaltmada etkili olmaktadır. Sosyal beceri eğitimi programları ile iletişim becerileri, girişken olma davranışları, sorun çözme becerileri gibi becerilerin geliştirilmesi amaçlanmaktadır.

Grupla psikolojik danışma uygulamalarının sıkılgan ergenlerin, sıkılganlık düzeyini azalttığı Akbaş (1999) tarafindan yapılan bir çalışmada ortaya konulmuştur. Yine Genç (2004) drama dersine katılan öğrencilerin utangaçlık düzeylerinin azaldığına dair bulgular elde etmiştir yaptı̆̆ 1 çalışmada. Hasdemir (2005), sosyal beceri eğitimi programını uyguladığı bir grup üniversite öğrencisinin utangaçlık düzeylerininin düştügünü ortaya koymuştur. Tüm bu bulgular özellikle grup etkileşimlerine dayalı, kişiler arası ilişkileri geliştirici programların utangaçlığ azalttığını göstermektedir.

Bu çalışmada yaratıcı dramanın oyunsu sürecinden yola çıkarak, doğaçlama, rol oynama, canlandırma gibi tekniklerin kullanıldığı grupla psikolojik danışma oturumları ile üniversite öğrencilerinin utangaçlık düzeylerinin azaltılması amaçlanmışıtır. Katılımcıların bir taraftan oyunsu süreçlerle gruba, grup çalışmalarına alışmaları, sonrasında da güvenli davranışları denemeleri psikolojik danışma oturumlarında desteklenmiştir. Yaratıcı drama ile grupla psikolojik danışma süreçlerinin birleştirilmesi açısından çalışma önemlidir.

\section{YÖNTEM}

$\mathrm{Bu}$ araştırmada "yaratıcı drama ile bütünleştirilmiş grupla psikolojik danışmanın üniversite öğrencilerinin utangaçlık düzeylerine etkisi" incelenmiştir. Araştırma ön-test, son-test kontrol gruplu karışık (split-plot) desenin kullanıldığı deneysel bir çalışmadır. Araştırmanın bağımsız değişkeni "drama ile bütünleştirilmiş grupla psikolojik danışma programı", bağımlı değişkeni de öğrencilerin utangaçlık ölçeği ile ölçülen "utangaçlık" düzeyidir.

Araştırma, Eğitim Bilimleri Fakültesinin farklı bölümlerine devam eden ve utangaçlık ölçeğinden yüksek puan almış 78 üniversite öğrencisi arasında seçilen 34 öğrenci ile yürütülmüştür. Grup çalışması öncesi deney ve kontrol gruplarına Utangaçlık ölçeği uygulanmış ve her iki grubun puan ortalamalarına bakılmıştır. 
Utangaçlık ölçeğinden alınan deney ve kontrol grupları öntest utangaçlık ölçeği puanları ortalamaları arasında anlamlı düzeyde bir farkın olup olmadığı, tek yönlü varyans analizi ile kontrol edilmiştir. Analizde anlamlılık düzeyi .01 alınmıştır.

\section{Tablo 1}

Gruplara Göre Utangaçlık Öntest Puan Ortalamalarının t-Testi Sonucu

\begin{tabular}{lllllll} 
Ölçüm & $\mathrm{N}$ & $\overline{\mathrm{X}}$ & $\mathrm{S}$ & $\mathrm{Sd}$ & $\mathrm{t}$ & $\mathrm{P}$ \\
Deney Grubu & 17 & 68.82 & 8.29 & 16 & 1.23 & .234 \\
Plas.Kontrol G. & 17 & 67.82 & 7.67 & & & \\
\hline p>.01 & & & & & &
\end{tabular}

Tablo-1 incelendiğinde araştırmanın bağımlı değişkeni olan utangaçlık düzeyi ile ilgili olarak yapilan t-testi sonucunda deney ve plesebo kontrol grubunun utangaçlık öntest puanlarının ortalamaları arasındaki farkın anlamlı olmadığı görülmektedir [t=1.23; $\mathrm{p}>.01]$.

\section{İşlem:}

Araştırmada deney ve plesabo kontrol gruplarına farklı programlar uygulanmıştır. Deney grubuna dramayla bütünleştirilmiş grupla psikolojik danışma uygulanırken, kontrol grubuna konuyla ilişkisiz farklı etkinlikler yapılmıştır. Deney grubu oturumları ortalama olarak 180 dakika, kontrol (plasebo) grubu oturumları ortalama 50 dakika sürmüştür. Deney ve kontrol grupları uygulamalarının bitiminde her iki gruba utangaçlık ölçeği tekrar uygulanmış ve öğrencilerin utangaçlık düzeyinde anlamlı bir fark olup olmadığına, dört ay sonra uygulanan izleme testi ile de bu farkın uzun süreli olup olmadığına bakılmıştır.

\section{Dramayla Bütünleştirilmiş Grupla Psikolojik Danışma Programı}

Yaratıcı dramanın bireyin kendini dışa vurmasına firsat tanıdığından, bağımsız düşünme becerisini geliştirdiğinden ve bireyde kendine güveni arttırdığından bireyin duygusal gelişimine önemli katkıları vardır. Yaratıcı drama ile bütünleştirilmiş grupla psikolojik danışma programı, üniversite öğrencilerinin utangaçlık düzeylerini azaltmak amacıyla farkındalık ve beceri kazandırmaya yönelik drama yöntem ve tekniklerinden yararlanılarak hazırlanmış bir psikolojik danışma programıdır. Program ağırlıkta bilişsel ve davranışçı yaklaşımın ilke ve teknikleri temel alınarak, drama ilke ve tekniklerinden yararlanılarak on oturum olarak planlanmıştır. Programın uygulanması için grupla psikolojik danışma bilgi ve becerileri ile bilişsel ve davranışçı yaklaşımın temel becerilerinin yanında, drama yöntem ve tekniklerinin de bilinmesini gerektirmektedir.

Yaratıcı drama ile bütünleştirilmiş grupla psikolojik danışmanın temel amacı, utangaçlığı başlatan ve sürdüren etkenlere ilişkin bilgilendirme ve bu durumu azaltmaya yardım edecek farkındalık ve başetmesine destek olacak beceriler kazandırmaya yönelik olarak yapılandırılmıştır. 
Program on hafta olarak planlanmıştır. Programda kendini tanıma, kişilerarası ilişkilerde yaşanın sıkıntıları ve bu sıkıntıların nedeninin farkına varma, sözel ve sözel olmayan iletişim becerilerini kazanma, akılcı olmayan düşünce ve temel inançların ve bu düşünce ve inançların davranıșlara etkisini farkedebilme amaçlanmıştır. Ayrıca yaratııı dramanın çalışmalarında kullanılan, canlandırma, doğaçlama, rol oynama, rol kartları, donuk imge, bilinç koridoru, gibi yöntem ve teknikler kullanılarak, bireylerin kendini ifade etmesi, temel sosyal beceriler kazanması ve kazandıkları becerileri sergilemeleri amaçlanmıştır. Program on oturumluk bir paket program olarak hazırlanmıştır. Utangaçlıkla başedilmenin deneysel bir programla test edilmesiyle, psikolojik yardım veren ve yaratıcı drama konularında yeterli meslek üyelerine yardımcı olacak bilgiler sunmak ve verilen yardımın daha etkili ve planlı sunulması amaçlanmaktır.

Programda ilk oturumda grubun oluşturulması, grup kurallarının ve bireysel amaçların belirlenmesi amaçlanmış, ikinci oturumda güven güvensizlik duyguları ve utangaçlık davranışları üzerine çalışılmış, üçüncü oturumda utangaç davranışların altındaki sistematik düşünce hataları ve devamında ortaya çıkan davranışlar üzerinde çalışılmış, dördüncü oturumda olumsuz temel inançlar üzerinde, ilerleyen oturumlarda iletişim becerileri, alternatif düşünce ve inançların yerleşmesi, yeni kazanılan davranışların sınanması, hayır diyebilme becerisinin kazandırılması, onaylanmama ve red edilme duyguları ile başedebilme, kısa ve uzun dönemli amaç belirleme ve güvenli davranışların sınanmasına yönelik çalışmalara yer verilmiş ve tüm uygulamalarda grupla psikolojik danışma sürecinde drama yöntemlerinin kullanılması esas alınmıştır.

\section{Veri Toplama Aracı}

Araştırmada deney ve kontrol grubu üyelerinin utangaçlık düzeylerini belirlemek amaciyla orijinali Cheek (1990) tarafindan 13 madde olarak geliştirilen Shyness Scala'nın, Güngör (2001) tarafindan Türkçe'ye uyarlaması yapılan formu kullanılmıştır. Kullanılan "Utangaçlık Ölçeği”" (Shyness Scala) 20 maddelik beşli likert tipi bir ölçektir.

\section{Ölçeğin Güvenirlik Çalışmaları}

Türkiye'de utangaçlık ölçeğinin güvenirlik çalışması Güngör (2001) tarafından iç tutarlılık ve test tekrar test yöntemi kullanılarak yapılmıştır. Ölçek 78 öğrenciye üç hafta ara ile iki kez uygulanması sonucunda elde edilen korelasyon katsayısı .83 olarak hesaplanmıştır. Ölçeğin iç tutarlılığını saptamak amaciyla hesaplanan Cronbach Alfa katsayısı .91 olarak hesaplanmıştır. Gökçe (2002)'nin çalışmasında ölçeğin, Cronbach Alfa katsayısı .87 olarak bulunmuştur. Bu araştırma kapsamında yapılan güvenirlik çalışmasında, ölçek, Ankara üniversitesi Eğitim Bilimleri Fakültesinde öğrenim gören toplam 255 üniversite öğrencisine uygulanmıştır. Ölçeğin iç tutarlılığını saptamak amacıyla Cronbach alfa .89 olarak hesaplanmıştır. $\mathrm{Bu}$ sonuç utangaçlık ölçeğinin iç tutarlılığı yüksek bir ölçek olduğunu göstermektedir. 


\section{Ölçeğin Geçerlik Çalıșmaları}

Utangaçlık ölçeğinin geçerlik çalışmaları Güngör (2001) tarafından yapılmıştır. Ölçeğin maddelerinin yapı geçerliğini belirlemek amacıyla, temel bileşenler analizi yapılmıştır. Analiz sonunda 20 maddenin toplam üç faktörde toplandığı görülse de, maddelerin çoğunluğunun tek faktörde toplandığı sonucuna varılmıştır. Geçerlik çalışması için kullanılan benzer ölçekler yönteminde Eren(1997) tarafindan geliştirilen "Sosyal Durumlarda Kendini Değerlendirme Envanteri" (SDKDE) uygulanmıştır. Her iki ölçek 84 kişilik bir üniversite öğrencisi grubuna uygulanmış ve iki ölçekler arasındaki korelasyon katsayıları "kaçınma" ve "sosyal kaygı" boyutları ile utangaçlık ölçeği puanı arasındaki .71, utangaçlık ile kaçınma boyutu arasında ise .78 olarak hesaplanmıştır. Ölçeğin lise öğrencileri formu için geçerlik çalışmasında Gökçe(2002)'nin hesaplamalarında kaygı boyutundan aldıkları puanlar ile korelasyon katsayısı .75, kaçınma boyutundan aldıkları puanlar arasındaki korelasyon katsayısı .72 ve kaygı ve kaçınma boyutlarından aldıkları toplam puanlar arasındaki korelasyon katsayısı .75 olarak hesaplanmıştır. Faktör Analiz sonucunda, ölçeğin 1. faktörünün varyansın \% 29.18'ini açıkladığını hesaplanmıştır (Gökçe,2002).

$\mathrm{Bu}$ araştırmada ölçeğin döndürülmüş temel bileşenler analizine bakıldığında, 20 maddenin 1. faktörde, .350 ile .765 arasında yük değerlerine sahip oldukları görülmüştür. Ölçek dört faktörlü bir yapı gösterse de, toplam varyansın $\% 55.92$ 'sini açıkladığı ve birinci faktörün toplam varyansın \%37.27'sini açıkladığı görülmektedir. Ölçeğin birinci faktörünün yük değerinin ve tek başına açıkladığ1 varyansın yüksek olması ölçeğin genel bir faktöre sahip olduğu şeklinde yorumlanmıştır. Ölçek, araştırmada utangaçlık düzeyini belirlemek ve programın etkililiğini test etmek amacıyla öntest-sontest ve izleme testi olarak üç kez uygulanmıştır.

\section{BULGULAR}

Araştırmada yaratıcı drama ile bütünleştirilmiş grupla psikolojik danışma oturumlarına katılan öğrencilerin utangaçlık düzeyleri, bu oturumlara katılmayan öğrencilerin utangaçlık düzeyinden önemli bir düzeyde azalma göstereceği ve bu azalmanın uzun süreli olacağı denencesi test edilmiştir. Deney ve kontrol grubunda yeralan öğrencilerin utangaçlık ölçeğinden aldıkları puanların öntest, sontest ve izleme ölçümü ortalamalarına ilişkin aritmetik ortalama ve standart sapma değerleri Tablo-2'de verilmiştir. 
Tablo 2

Gruplara Göre Utangaçlık Ölçeği Puanlarının Betimsel Istatistikleri

\begin{tabular}{lllll}
\hline Ölçüm & Grup & $\mathrm{N}$ & $\mathrm{X}$ & $\mathrm{S}$ \\
\hline Öntest & Deney grubu & 17 & 68.82 & 8.29 \\
& Pls.Kontrol grubu & 17 & 67.82 & 7.67 \\
& Toplam & 34 & 68.32 & 7.88 \\
\multirow{3}{*}{ Sontest } & Deney grubu & 17 & 39.35 & 10.13 \\
& Pls.Kontrol grubu & 17 & 68.41 & 11.86 \\
& Toplam & 34 & 53.88 & 18.32 \\
\multirow{3}{*}{ İzleme Testi } & Deney grubu & 17 & 38.59 & 9.64 \\
& Pls.Kontrol grubu & 17 & 67.00 & 12.22 \\
& Toplam & 34 & 52.79 & 18.04 \\
\hline
\end{tabular}

Tablo-2'de yer alan ortalama puanlar dikkate alındığında deney öncesi, deney ve kontrol grupları puan ortalamaları arasında anlamlı bir fark görülmezken, deney sonrası sontest puanlarında utangaçlık puan ortalamaları arasında farklılık olduğu görülmektedir. İzleme ölçümlerine bakıldığında, deney grubu öntest ve sontest puanları arasındaki anlamlı bir fark görülürken, kontrol grubunda bu farkın olmadığı görülmektedir. Deney ve kontrol gruplarının tekrarlı ölçümlerinden elde edilen toplam puanlar arasında anlamlı fark ve bu farkın işlem gruplarında anlamlılık gösterip göstermediğini belirlemek amacıyla yapılan tekrar edilmiş ölçümlere uygun varyans analizi (ANOVA) sonuçları Tablo-3'da verilmiştir.

Tablo 3

Utangaçlık Ölçeği Öntest Sontest ve İzleme Testi Puanlarının Anova Sonuçları

\begin{tabular}{lcccccc}
\hline Varyansın Kaynağı & KT & Sd & KO & F & P & Eta-Kare \\
\hline Gruplararası & 14968.000 & 33 & & & & \\
Grup (D/K) & 9035.294 & 1 & 9035.294 & 48.73 & .000 & .60 \\
Hata & 5932.706 & 32 & 185.397 & & & \\
Gruplariçi & 13998.666 & 68 & & & & \\
Ölçüm (Ön-Son-İzleme) & 5110.137 & 2 & 2555.069 & 42.18 & .000 & .57 \\
Grup Ölçüm* & $\mathbf{5 0 1 2 . 1 7 6}$ & $\mathbf{2}$ & $\mathbf{2 5 0 6 . 0 8 8}$ & $\mathbf{4 1 . 3 8}$ & $\mathbf{. 0 0 0}$ & $\mathbf{. 5 6}$ \\
Hata & 3876.353 & 64 & 60.568 & & & \\
Toplam & 28966.666 & 101 & & & & \\
\end{tabular}

$$
* \mathrm{p}>.01
$$

Tablo-3 incelendiğinde deney ve kontrol gruplarının deney öncesi ve deney sonrası öntest ve sontest toplam utangaçlık puanları arasında .01 düzeyinde anlamlı bir farkın olduğu görülmektedir. Bu bulgu deney ve kontrol gruplarında bulunan 
öğrencilerin utangaçlık puanlarının ölçüm ayrımı (deney öncesi - deney sonrası) yapmaksızın farklılaştığını göstermektedir. Ayrıca, öğrencilerin utangaçlık puanları ile ilgili olarak öntest-sontest ortalamaları arasında da .01 düzeyinde anlamlı bir fark vardır $[F(2-64)=41.38, p<.01]$. Bu farkın yaratıcı drama ile bütünleştirilmiş grupla psikolojik danışma programından kaynaklandığı söylenebilir. Ortak etkinin kaynağını daha net yorumlamak amacıyla gözenek ortalamaları arasındaki farkların manidarlığ Tukey q testi ile incelendiğinde, Tablo 4'de görüldüğü gibi deney grubunda öğrencilerin sontest puanları öntest puanlarına göre; izleme testi puanları öntest puanlarına göre manidar bir şekilde düşüktür. $\mathrm{Bu}$ grupta, sontest ve izleme testi puan ortalamaları arasında manidar fark yoktur. Kontrol grubunda, ölçümler arasındaki tüm farklar manidar değildir. Öntest puanları dikkate alındığında deney ve kontrol grupları arasında manidar fark yok iken, sontest ve izleme testi puanlarında deney grubunun ortalama puanı manidar bir şekilde daha düşüktür.

\section{Tablo 4}

Ortak Etkiyle İlgili Olarak Gözenek Ortalamalar İçin Tukey q Testi Sonuçları

\begin{tabular}{|c|c|c|c|c|c|}
\hline \multirow{2}{*}{ Faktör } & \multirow{3}{*}{ Düzey } & Ölçümler & \multicolumn{2}{|c|}{ Aras1 } & \multirow{2}{*}{$\begin{array}{l}\text { Gruplararasi }{ }^{\mathrm{b}} \\
\mathrm{Q}\end{array}$} \\
\hline & & q & & & \\
\hline & & $\begin{array}{l}\text { Öntest - } \\
\text { Sontest }\end{array}$ & $\begin{array}{l}\text { Öntest - } \\
\text { İzleme }\end{array}$ & $\begin{array}{l}\text { Sontest- } \\
\text { İzleme }\end{array}$ & $\begin{array}{l}\text { Deney - } \\
\text { Kontrol }\end{array}$ \\
\hline \multirow[t]{2}{*}{ Grup } & Deney & $15.59 *$ & $15.99 *$ & 0.76 & - \\
\hline & Kontrol & 0.31 & 0.96 & 0.75 & - \\
\hline \multirow[t]{3}{*}{ Tekrarlı Ölçüm } & Öntest & - & - & - & 0.41 \\
\hline & Sontest & - & - & - & $11.86^{*}$ \\
\hline & İzleme & - & - & - & $11.60 *$ \\
\hline
\end{tabular}

a Tablo Değeri : $\mathrm{q}_{(.05 ; 3-64)}=3.40$

b Tablo Değeri : $\mathrm{q}^{1}(.05)=2.87$

$* \mathrm{p}<.05$

Araştırmada elde edilen bu sonuçlar, araştırmanın denencesini desteklemektedir. Gruplar arasındaki bu farkın uygulanan programdan kaynaklandığı sonucuna varılmıştır. Başka bir anlatımla, yaratıcı dramayla bütünleştirilmiş grupla psikolojik danışma programı öğrencilerin utangaçlık düzeyinde manidar bir azalmaya neden olmakta ve bu düşüş de kalıcı olmaktadır.

\section{TARTIŞMA VE ÖNERILER}

$\mathrm{Bu}$ araştırma bulguları drama yöntem ve tekniklerinin kullanıldığı grupla psikolojik danışma oturumlarının bireylerin utangaçlık düzeyini azaltmada etkili olduğunu ortaya koymuştur. Bu bulgu, Akbaş (1999)'ın grupba psikolojik danışma uygulamalarının sıkılganlık düzeyini azalttığı yönündeki bulguyu, Genç (2004)'in 
yaratıcı drama dersinin öğrencilerin utangaçlık düzeyini azalttığı ve Hasdemir (2005)'in sosyal beceri eğitiminin lise öğrenilerinin utangaçlık düzeyini azalttı̆̆ yönündeki bulgularını desteklemektedir. Utangaç insanların utangaçlıklarıyla başetmek için neler yapıldığını belirlemeye yönelik önceki araştırmalar (Carducci ve Zimbardo, 1995; Carducci, 2000) göstermektedir ki, insanlar utangaçlı̆̆ın üstesinden gelmek için pek çok çaba harcamaktadırlar. Bu çabaların başarısız olma nedeni büyük oranda utangaçların kullandıkları yanlış ve yetersiz stratejilerdir. $\mathrm{Bu}$ stratejiler bazen yarar yerine zarar bile vermekte, hatta utangaçlıklarıyla başetmede potansiyel riskler bile oluşturmaktadır. Utangaçlar için hazırlanmış başetme programları utangaçların doğru yolda ilerlemeleri ve doğru stratejiler belirlemeleri açısından önemlidir (Carducci,2000). Utangaçların \%50'si yardımcı kitap ve büyük seminerlere yönelmekte, utangaçların \%20'si utangaç olmamak için, kendileriyle konuşmayı denemektedir (Carducci, 2000). Fakat insanların sadece bunları yapmaları utangaçlıklarını azaltmada yeterli olmamaktadır, grupla psikolojik danışma (Akbaş 1999), yaratıcı drama (Genç 2004) sosyal beceri eğitimi (Hasdemir 2005) ve çalışmada denenen dramayla bütünleştirilmiş grupla psikolojik danışma uyulamaları daha etkili yöntemler olarak ortaya çıkmaktadır.

Utangaçlığın çözümlerinden biri de onun iç dinamiklerini iyi anlamaktır. Utangaç insan, sade bir şekilde stresli ortamlarda veya yeni durumlarda uyum sağlamak için, günlük sohbetlerde ve sosyal toplantılarda ekstra zamana ihtiyaç duyar. Onlar yaşamın gelişimsel engellerini yönetmek için, diğer insanlardan daha çok zamana ihtiyaç duyarlar (Clements ve Avery,1984; Carducci,2000; Crozier,2001). Yaratıcı drama grupla kaynaşma sürecinde bireyin ihtiyaç duyduğu bu ekstra ısınma zamanını bireye tanımaktadır.

Utangaçlı̆̆ azaltmada; rol oynama, canlandırmalar, doğaçlamalar, çeşitli davranış provalarının yapılmasının olumlu etkiye sahip olduğu benzer araştırma bulgularıyla da desteklenmektedir. Çalışma sonuçları, Barrow ve Hayashi (1980); Clements ve Avery (1984); Beuge (1993); Walsh-Bowers ve Basso (1999); Akbaş, 1999, Yassa (1999); Genç, (2004) ve Hasdemir (2005)'nn araştırma bulgularıyla paralellik göstermektedir.

Drama aynı zamanda utangaçlığın azaltılmasında değil, utangaçlığın kavranmasını da sağlar. Çünkü bireyler özel sorunlarını bile tepkiyle karşılanmaksızın ya da cezalandırılma kaygısı taşımaksızın grup ortamında paylaşabilirler. Drama bireylere kendileri gibi davranma ve hissetme özgürlü tanıdığı için bu davranışların tekrarlanma olasılığını da arttırmaktadır. Nitekim Genç (2004) tarafindan yapılan çalışmada, drama eğitimi almış sınıf öğretmenliği öğrencileri ile almamış, meslek yüksek okulu öğrencilerinin utangaçlık düzeyleri arasında anlamlı bir fark olması da, bu araştırma bulgularını destekleyen bir sonçtur. Dramanın utangaç bireyleri güdülediği ve kendilerini daha rahat açabildiklerini ortaya koymuş, utangaçlı̆̆ı azaltmıştır. 
$\mathrm{Bu}$ çalışmada yer verilen iletişim becerilerinin geliştirilmesine yönelik uygulamaların da, yüzyüze iletişim kurmada güçlük, iletişim kurmada isteksizlik ve sosyal etkinliklere katılmada ortaya çıkan kaçınma davranışları ve kendini ifade etme noktasındaki sosyal beceri eksikliklerini azaltmada etkili olduğu ortaya çıkmıştır. Bu bulgu alan yazında yeralan benzer araştırma sonuçlarıyla (Avey, Clements ve Lemke 1981; Hasdemir, 2005) paralellik göstermektedir. Utangaç bireylerin utangaçlıklarını azaltmada, önceki araştırma bulguları ile) İletişim becerilerinin kazanılmasının, İletişim becerileri kazanmış olan bireylerin utangaç davranışlar gösterme eğilimleri azalmaktadır.

Sonuç olarak; bu araştırma kapsamında hazırlanan grup programı grup oturumlarına katılan öğrencilerin utangaç olma davranışlarını azaltmada etkili olmuştur. Araştırmanın sonuçları, literatürdeki araştırma bulguları ile bütünleşerek yapılandırılmış yaratıcı drama ile bütünleştirilmiş grupla psikolojik danışmanın bireylerin utangaçlık düzeylerini azaltmada etkili olduğuna ilişkin deneysel sonuçlara yeni bir bulgu sağlamıştır. Bu bölümde araştırmadan elde edilen bulgular 1şığında şu öneriler sunulabilir:

1. Yaratıcı drama, özellikleri ve kuralları açısından eleştiriden uzak ve kesin doğru ve yanlışların olmadığı bir ortam sunduğundan kendini ifade etmede güçlük yaşayan bireyler için son derece uygun zengin bir ortam sunmaktadır. Bu nedenle bireyin kendini tanıması, toplumla sağlıklı bir uyum içinde olmasını sağlamaya çalışan psikolojik danışma oturumları için drama yöntem ve teknikleri yaşantıya dayalı ve katılıcı etkiler sunmaktadır.

2. Utangaçlığın nedeni ve ortaya çıkmasında kültürel ve çevresel çok fazla faktör rol oynamaktadır. Bu nedenle utangaçlık farklı toplum ve kültürlerde farklı davranış kalıplarıyla ortaya çıkmaktadır. Bu özelliği nedeni ile utangaçlığı azaltmak amaciyla hazırlanan programlarda ortak bir standart oluşturmak zordur, her program, her utangaç birey için uygun olmamaktadır. Programların hazırlanmasında bu bireylerin ihtiyaç ve özellikleri gözönünde bulundurulmalıdır.

3. Utangaç bireyde hata yapma, olumsuz değerlendirilme ve eleştirilme korkusu çok belirgindir. $\mathrm{Bu}$ korkular bireyde kaçınma davranışlarına neden olmaktadır. Yaratıcı drama ve grupla psikolojik danışma özellikle değerlendirilme korkusu olmaksızın, eleştirilmeden ve hata yapma korkusu taşımaksızın yaşanan bir süreç olması bakımından özellikle kendini bu korkulardan dolayı ifade etmekte zorlanan bireyler için son derece olumlu ortamlar sunmaktadır.

4. Yaratıcı dramanın, grupla psikolojik danışma sürecine katkısını daha belirgin olarak saptayabilmek için hazırlanan programın "yaratıcı drama ile bütünleştirilmiş" ve sadece "grupla psikolojik danışma" ile uygulandığı iki deney gruplu (karşılaştırmalı) bir araştırma yapılabilir.

Sonuç olarak okul psikolojik danışmanlarının utangaç öğrencilere yönelik drama ve grupla psikolojik danışma uygulamaları ve bu araştırmada hazırlanan uygulamalardan yararlanarak öğrencilere yardımcı olmaları önerilebilir. 


\section{KAYNAKLAR}

Adıgüzel.H.Ö (Ed). (1994). Eğitimde yeni bir yöntem ve disiplin: yaratıcı drama. Yaratıcı Drama. 1985-1995 Yazılar.(Ö.Adıgüzel, Ed.) Ankara: Naturel Yayınevi .

Akbaş, A.(1999). Grupla psikolojik danışmanın ergenlerin sıkılganlık düzeyine etkisi. 4. Ulusal Eğitim bilimleri Kongresi Bildirileri-4. Eskişehir: Anadolu Üniversitesi.

Amico, K.R.., Bruch, M.A.., Haese, R.F. \& Sturmer, P.J. (2003). Trait shyness, actual-ought self-discrepancy and discomfort in social interaction. Personality and Individual Differences, 36, (7), 1597-1610

Arends, T. (2000). Understanding Shyness. (May, 2000) URL: www. http:// members.aol.com/ cybernettr/shyness.html.

Asendorpf. J.B.and Meier, G.H.(1993). Personality effects on children's speech in everyday life: Journal of Personality and Social Psychology. 64, 1072-1083.

Asendorpf, J.B. and Wilpers, S.(1998). Personality effects on social relationships. Journal of Personality and Social Psychology 74, 1531-1544.

Avery,A.W., Clements, H.L.\& Lamke, L. (1981). Teaching shy studens: the role of the family life educator. Family Relations, January. 30, 39-43.

Barrow,J.\&Hayashi, J.(1980). a social development program for adolescents and young adults. The Personnel And Guidance Journal. September.

Buege, C.(1993). The effects of mainstreaming on attitude and self concept using creative drama and social skills traninig. Youth Theatre Journal. 7. (3).

Burger, J.M.(2006). Kişilik. (çev. İnan D.E.Sarığlu)Kaknüs psikolojisi, kaknüs yayınları. İstanbul.

Buss, A.H. \& Plomin, R.(1984).Temperament: Early developing personality traits, Erlbaum, Hillsdale, NJ (1984).

Buss, A.H.(1986). A theory of shyness. In: Jones, W.H., Cheek, J.M. and Briggs, S.R., Editors, 1986. Shyness: Perspectives on research and treatment, Plenum Press, New York, 39-46.

Cabak, H.(2002). Lise öğrencilerin utangaçlık düzeylerinin bazı değişkenler açısından incelenmesi.(Yayınlanmamış Yüksek Lisans Tezi). Malatya: İnönü Üniversitesi Sosyal Bilimler Enstitüsü.

Carducci, J.B \& Zimbardo,G.F (1995) Are you shy? Psychology Today. 28 (6) 3446

Carducci, J.B. (2000). Shyness The New Solution. Psychology Today. Jan/Fab. Vol.33. İs.1. 
Cheek, J.M., \& Buss, A.H. (1981). Original 9-item version Shyness and sociability. Journal of Personality and Social Psychology, 41, 330-339.

Cheek, J.M., \& Briggs, S.R. (1990). Shyness as a personality trait. In W.R. Crozier (Ed.).Shyness and Embarrassment: Perspectives from Social Psychology (pp. 315 - 337). Cambridge, UK: Cambridge University Press.

Clark, D.M. and Wells, A., (1995). A cognitive model of social phobia. Editors,1995. Social phobia: Diagnosis, assessment, and treatment. The Guilford Press, New York, pp. 69-93.

Clements,H.L.\& Avery,A.W (1984) A Cognitivite Behavioral Approach to Social Skills Training With Shy Persons. Journal of Clinical Psychology, May.Vol.40.No:3

Crawford, L\&Taylor, L (2001). Çekingenlik. (Çeviri: Murat Sağlam). İstanbul: Alfa Yayınevi.

Crozier, W.R.(2001).Shyness: Development,Consolidation\&Change. Routledge

Duck, S.(1986). Human Relationships. Londan:Beverly Hills:New Delhi: Sage Publications.

Ekşi, A. (1990). Çocuk Genç ve Ana-Babalar. Ankara: Bilgi Yayınevi.

Erdal,H..(2003). Çalışan ve Çalışmayan Kadınların Utangaçlıklarının Bazı Değiş̧kenler Açısından Incelenmesi.Yayınlanmamış Yüksek Lisans Tezi. Ankara: Hacettepe Üniversitesi Sosyal Bilimler Enstitüsü.

Eysencek, H.J. (1983). The Social Application of Pavlovian Theories. Pavlovian Journal of Biological Science, 18. 117-125.

Freeman, G.D. Sullivan, K.\& Fulton, C. R (2003). Effects of Creative Drama on Self-Concept, Social Skills, and Problem Behavior. Journal of Educational Research; Vol. 96 Issue 3, p131, 8p

Fyer, A.J., Mannuzza, S., Chapman, T.F., Martin, L.Y. and Klein, D.F., (1993). A Direct Interview Family Study of Scial Phobia. Archives of General Psychiatry. 50, pp. 286-293.

Genç, N. (2004) Drama Dersinin Üniversite Öğrencilerinin Utangaçlık Düzeylerine Etkisi. Drama Liderliği. (Editör. Naci Aslan). Türkiye 6. Drama Liderleri Buluşması ve Ulusal Drama Semineri. Ankara: Oluşum Yayınları.

Gökçe, S. (2002) Lise Öğrencilerinin Utangaçlık Düzeylerinin Yordanmast. (Yayımlanmamış yüksek lisans tezi). Gazi Üniversitesi Eğitim Bilimleri Enstitüsü, Ankara..

Güngör, A. (2001) Utangaçlık Ölçeğinin Geliştirilmesi Geçerlik ve Güvenirlik Çalışmaları. Türk Psikolojik Danışma ve Rehberlik Dergisi, 2 (15), 17-22. 
Hasdemir, A.(2005) Sosyal Beceri Ĕ̆itiminin Lise Öğrencilerinin Utangaçlık Düzeylerine Etkisi. (Yayınlanmamış Yüksek Lisans Tezi). Ankara Üniversitesi Eğitim Bilimleri Enstitüsü. Ankara.

Henderson, L \& Zimbardo, F.G. (1998) Shyness. Encyclopedia of Mental Health . San Diego: Academic Press.

Heiser, N.A., Turner, S.M. and Beidel, D.C (2003). Shyness: Relationship to Social Phobia and Other Psychiatric Disorder. Behaviour Research and Therapy. 41. 209-221.

Jackson ve diğerleri (2002) Towards Explaning The Association Between Shyness and Lonelliness: A Path Analaysis With American Collage Students. Social Behavior And Personality. 30(3). 263-270

Jones, Briggs and Smith, (1986).W.H. Jones, S.R. Briggs and T.G. Smith, Shyness: conceptualization and measurement. Journal of Personality Social Psychology. 51 pp. 629-639.

Kagan J. (1992). The nature of shyness. Harvard Mag 94:41-45.

Kelly, L.(1982) A Rose by Any Another Name İs Still A Rose: A Comparative Analysis of Reticence, Communication Apprehension, Unwillingness to Communicate and Shyness' Human Communication Researcah (8), 99-113.

Leary,M.R.\&Dobbins,S.E. (1983) Social Anxiety, Sexual Behavior, and Contraceptive Use. Journal of Personality and Social Psychology (47) 75-94

Lorant, T.,Henderson, L. and Zimbardo, P. (2000). Comorbidity In Chronic Shyness. Depression And Anxiety 12:232-237

Markway, B\&Carmin. N Pollard, Flynn, 1998.(1998). Utangaçlı̆̆ı Yenmek Çekingen ve Sıkılganlar İçin El Kitabı. (Çeviri; Raziye Karabey). İstanbul. Mavi Psikoloji

Netro, F. \& Mullet, E. (2004). Personality, Self-Esteem and Self-Construal as Correlates of Forgivingness. European Journal of Personality, Vol.18.Issue 1.s. 15 .

Payne, K.(2005) Understandıng And Overcomıng Shyness.http//. www. Counseling Center. com. (kasim-2005).

Pilkonis, P.A (1977).The Behavioral Consequences of Shyness. Journal of Personality. (45), 596-611

San,İ.(1989) yaratıcı estetik eğitim. Ankara Üniversitesi Eğitim Bilimleri Fakültesi yayınlar1. Ankara:

Smith, H.M \& Betz, N.E (2002). An Examination of Efficacy and Esteem Pathways to Depression in Young Adulthood. Journal of Counseling psychology. Vol. 49. İssue, 4. 438. 
Stein, W. \& Walker, J.R. (2001) Triumph Over Shyness: Conquering Shyness \& Social Anxiety. McGraw-Hill Education Group

Walsh-Bowers, R. \&Basso, R. (1999) Improving early adolescents' peer relations through classroom creative drama: An integrated approach. Social Work in Education; Jan99. Vol. 21 Issue 1, p. 23-32

Walsh, J. (2002). Shyness and Social Phobia. Health \& Social Work. Vol. 27. Issue. 2. s. 137.

Yassa,N. (1999). High School Involvement In Creatıve Drama, Research In Drama Education, 1356-9783, February 1, 1999, Vol. 4, Issue 1.

Yolaç, P. (1998) Sosyal fobide bilişsel-davranışçı tedavi yaklaşımı. Bilişsel davranış̧̧ı terapiler.(Editörler:Savaşır,I., Boyacıoğlu,G. ve Kabakçı,E.).Geliştirilmiş II. Baskı. Türk psikologlar derneği yayınları.

Yüksel, G. (2003) Üniversite ÖğrencilerininUtangaçlık Düzeylerini Etkileyen Faktörler. Gazi Eğitim Fakültesi Dergisi. Ankara: GEF yayını

Zimbardo et al., (1975). P.G. Zimbardo, P.A. Pilkonis and R.M. Norwood, The social disease called shyness. Psychology Today 8 (1975), pp. 68-72.

Zimbardo, G.P. (1977) Shyness: What is it and what to do about it. Reading, MA: Addison-Wesley Publishing Company. 